\title{
EU Equality Law and Precarious Work
}

\author{
Mark Bell ${ }^{\bullet}$ \\ Pre-proof text. Final version in Uladzislau Belavusau \& Kristin Henrard (eds.), EU Anti-Discrimination Law Beyond Gender, \\ Hart 2019
}

The economic crisis accentuated debate around precariousness in the labour market. This is connected to a longer-term trajectory of growth in jobs that diverge from the characteristics of the 'standard employment relationship' (SER); ${ }^{1}$ in other words, the traditional image of a full-time, permanent worker who was directly employed by the provider of work. Precarity is a contested concept that is open to a range of interpretations, but it is often linked to concerns around a decline in job security and an increase in low quality, low wage forms of employment. ${ }^{2}$ Some readings of precarious work view this as synonymous with specific types of employment relationship, such as part-time, fixed-term, agency or casual work. ${ }^{3}$ In contrast, other interpretations focus on identifying the characteristics of precariousness in the labour market, which may arise in any form of employment. ${ }^{4}$ One of the most commonly cited approaches is that of Rodgers, who connected the precariousness of work to variables such as: the degree of certainty of continuing work; the control enjoyed by workers (for example over working conditions); the extent of protection of workers; and the level of income. ${ }^{5} \mathrm{He}$ argued that 'it is some combination of these factors which identifies precarious jobs, and the boundaries around the concept are inevitably to some extent arbitrary' ${ }^{6}$

\footnotetext{
- Regius Professor of Laws, Trinity College Dublin.

${ }^{1}$ Sonia McKay, 'Disturbing Equilibrium and Transferring Risk: Confronting Precarious Work' in Nicola Countouris and Mark Freedland (eds), Resocialising Europe in a Time of Crisis (Cambridge University Press 2013) 191, 203.

${ }^{2}$ Lisa Rodgers, Labour Law, Vulnerability and the Regulation of Precarious Work (Edward Elgar 2016) 5 .

${ }^{3}$ Leah Vosko, Martha MacDonald, and Iain Campbell, 'Gender and the Concept of Precarious Employment' in Leah Vosko, Martha MacDonald, and Iain Campbell (eds), Gender and the Contours of Precarious Employment (Routledge 2009) 1, 6.

${ }^{4}$ Ibid. See also, Arne Kalleberg, 'Precarious Work, Insecure Workers: Employment Relations in Transition' (2009) 74 American Sociological Review 1; Judy Fudge and Rosemary Owens, 'Precarious Work, Women, and the New Economy: the Challenge to Legal Norms' in Judy Fudge and Rosemary Owens (eds), Precarious Work, Women, and the New Economy: the Challenge to Legal Norms (Hart Publishing 2006) 3, 11.

${ }^{5}$ Gerry Rodgers, 'Precarious Work in Western Europe: the State of the Debate' in Gerry Rodgers and Janine Rodgers (eds), Precarious Jobs in Labour Market Regulation: the Growth of Atypical Employment in Western Europe (International Institute for Labour Studies 1989) 1, 3. 6 ibid.
} 
EU employment law and policy since the 1990s has sought to encourage labour market flexibility within the Member States, including diversity in the range of employment relationships. ${ }^{7}$ This prompts fears that the pursuit of flexibility may lead to precariousness through a deterioration in the protections associated with the SER. The EU has tried to counter such worries through the notion of 'flexicurity', which entails a trade-off between reduced security in one's current job, in exchange for a stronger safety net of social protection and active labour market policy to enable individuals to make transitions between jobs throughout their working lives. ${ }^{8}$ One ingredient in this policy recipe has been improving the quality of diverse forms of employment relationship in an effort to make these seem more palatable, and less precarious, for workers who are no longer able to secure work under SER conditions. In legislative terms, this has taken the form of several Directives on 'atypical' work, most notably those on Part-Time Work, Fixed-Term Work and Agency Work. ${ }^{9}$ The subsequent case-law on part-time and fixed-term work has demonstrated the potential of the legislation to be used as an instrument for combating precariousness, albeit imperfect and constrained in its effects. For example, the Court of Justice of the EU (CJEU) has rejected the idea that employers can, without rigorous justification, exclude part-time and fixed-term workers from important benefits such as length-ofservice pay increments, or access to occupational pensions. ${ }^{10}$

While the Atypical Work Directives are an obvious point of reference when thinking about how labour market precariousness can be tackled, it is important to recognise the complementary role of EU equality law. The marginalisation of parttime workers has been a recurrent theme of gender equality case-law since the seminal decision in 1986 in Bilka-Kaufhaus. ${ }^{11}$ In that case, the CJEU held that excluding part-time workers from an occupational pension scheme could constitute indirect sex discrimination where the exclusion affected 'a far greater number of women than men'. ${ }^{12}$ While the nexus between part-time work and gender equality is

\footnotetext{
${ }^{7}$ Nicola Kountouris, 'The Legal Determinants of Precariousness in Personal Work Relations: A European Perspective' (2012) 34 Comparative Labor Law \& Policy Journal 21, 38.

8 ibid 39; Rodgers (n2) 111.

${ }^{9}$ Council Directive (EC) 97/81 Concerning the Framework Agreement on Part-Time Work Concluded by UNICE, CEEP and the ETUC [1998] OJ L14/9; Council Directive (EC) 1999/70 Concerning the Framework Agreement on Fixed-Term Work Concluded by ETUC, UNICE and CEEP [1999] OJ L175/43; European Parliament and Council Directive (EC) 2008/104 on Temporary Agency Work [2009] OJ L327/9.

${ }^{10}$ eg Case C-307/05 Del Cerro Alonso v Osakidetza-Servicio Vasco de Salud [2007] ECR I-7109; Case C-268/06 IMPACT v Minister for Agriculture and Food and others [2008] ECR I-2483; Case C-177/14 Regojo Dans v Consejo de Estado, EU:C:2015:450.

${ }^{11}$ Case 170/84 Bilka-Kaufhaus GmbH v Weber Von Hartz [1986] ECR 1607.

12 ibid para 31 .
} 
well-established, less attention has been paid to the way in which other protected characteristics intersect with precarious work. For example, the risk of being underemployed for non-EU nationals is more than double that for EU citizens living in their state of nationality. ${ }^{13}$ Research has indicated that disabled people can be overrepresented amongst those working part-time, ${ }^{14}$ while data in the UK has uncovered an over-representation of black and minority ethnic workers in areas like temporary work, agency work, low paid work and under-employment. ${ }^{15}$ Other research has also drawn attention to the impact of age on labour market experience; 'very atypical' forms of work are more common amongst those aged under 29 or over 50. ${ }^{16}$

This chapter explores developments since 2000 to consider the role of EU equality law in relation to precarious work. While recognising that precariousness cannot be reduced to specific types of employment relationship, Vosko et al note that operationalising this concept frequently entails beginning with certain forms of employment, such as part-time or fixed-term work, which are associated with precarity. ${ }^{17}$ In this vein, particular attention will be paid to how EU equality directives have been used by those in non-standard employment relationships. Taking into account the state of the existing case-law, the chapter will focus on the characteristics of gender and age. These have both witnessed litigation since 2000 on issues linked to precarious work, thus providing an opportunity to assess the contribution being made by equality directives.

\section{Gender Equality Directives and Precarious Work}

The gendered nature of precarious work is most visible in relation to part-time work. In $2015,19.6 \%$ of those working in the EU were part-time. ${ }^{18} 32.1 \%$ of women work part-time, but the figure for men is $8.9 \% .{ }^{19}$ At first glance, it might not seem evident why part-time work is connected with precarious work. Unlike fixed-term work, parttime work is not necessarily insecure in terms of its duration. In contrast to agency

\footnotetext{
${ }^{13}$ Eurostat, 'Underemployment and Potential Additional Labour Force Statistics' (2016): $<$ http://ec.europa.eu/eurostat/statistics-

explained/index.php/Underemployment_and_potential_additional_labour_force_statistics $>$ accessed 21 February 2017.

${ }^{14}$ Tom Shakespeare, Disability Rights and Wrongs Revisited (2 $2^{\text {nd }}$ edn, Routledge 2014) 32.

15 TUC, 'Living on the Margins: Black Workers and Casualisation' (2015), available at: $<$ https://www.tuc.org.uk/node/122625> accessed 21 February 2017.

${ }^{16}$ European Foundation for the Improvement of Living and Working Conditions, 'Very Atypical Work: Exploratory Analysis of Fourth European Working Conditions Survey' (European Foundation 2010) 28.

17 Vosko et al (n3) 13.

${ }^{18}$ European Commission, 'Employment and Social Developments in Europe. Annual Review 2016' (Publications Office of the European Union 2016) 215.

${ }^{19}$ Ibid 216.
} 
work, part-time workers will often have a clear contractual relationship with the provider of employment. Moreover, many workers seem content with this form of work. The 2005 European Working Conditions Survey found that over $80 \%$ of parttime workers were satisfied with their working conditions, which was equivalent to the rates of job satisfaction for full-time workers. ${ }^{20}$ Nevertheless, the precariousness of part-time work stems from its association with low occupational status, low pay and low protection in terms of employment law and social security. The ILO's 2007 global report concluded that:

in most countries part-time work remains women's work and is synonymous with low status, low training and limited career opportunities, despite its being often presented as available to both working mothers and fathers. Moreover, part-time may often be involuntary, in the sense that it is a second-best option to a full-time job. ${ }^{21}$

Involuntary part-time work is connected to under-employment, where the worker would prefer longer working hours. $22.2 \%$ of part-time workers in the EU are underemployed, of which $67 \%$ are women. ${ }^{22}$ In some Member States, involuntary part-time work has become a striking feature of the labour market during the economic crisis. In Greece, for example, $72.1 \%$ of those working part-time were under-employed, while the figure was $57.3 \%$ in Spain. ${ }^{23}$ The high rate of female part-time workers who are under-employed may disclose a covert phenomenon of casual work. This is connected to the growth, in some states, of part-time work with a low number of guaranteed weekly hours. ${ }^{24}$ The worker is often willing to accept any additional work that is offered by the employer (in order to raise their income). Therefore, she needs to keep herself available in case extra work arises. This psychological uncertainty exacerbates the dependency on the employer. ${ }^{25}$ Rodgers suggests that the most precarious forms of part-time work, such as those with a high variability in working time, often blend with other categories of atypical work, such as temporary or casual work. ${ }^{26}$ This is supported by research on 'very atypical' work in Europe, which found that those

\footnotetext{
${ }^{20}$ European Foundation for the Improvement of Living and Working Conditions, 'Part-time work in Europe: European Company Survey 2009' (Publications Office of the European Union 2011) 22.

${ }^{21}$ ILO, 'Equality at Work: Tackling the Challenges. Global Report Under the Follow-Up to the ILO Declaration on Fundamental Principles and Rights at Work' International Labour Conference $96^{\text {th }}$ session 2007, report I(B), 78 .

${ }^{22}$ Eurostat, 'Almost 10 million part-time workers in the EU would have preferred to work more' (2015) <http://ec.europa.eu/eurostat/fr/web/products-press-releases/-/3-27042015-AP> accessed 21 February 2017.

23 ibid.

24 Vosko et al (n3) 16.

25 Jenny Julén Votinius, 'On the Gendered Norm of Standard Employment in a Changing Labour Market' in Judy Fudge and Rosemary Owens (eds), Precarious Work, Women, and the New Economythe Challenge to Legal Norms (Hart Publishing 2006) 265, 268.

${ }^{26}$ Rodgers (n5) 4.
} 
working less than 10 hours per week were less likely to have an indefinite contract than those with longer working hours. ${ }^{27}$ Women were, in general, over-represented amongst those in 'very atypical' work, which may also reflect its concentration in certain sectors, such as hotels and restaurants. ${ }^{28}$

Gender differences in relation to other forms of work associated with precariousness are less pronounced. In the EU, women are slightly over-represented amongst those engaging in fixed-term work, with a rate of $12.8 \%$ compared to $11.2 \%$ for men. ${ }^{29}$ In contrast, men have a higher rate of self-employment: ${ }^{30} 18.8 \%$ as opposed to $10.4 \%$ among women. ${ }^{31}$ Even where participation rates are similar, it must be recognised that the impact of precarious work on women may differ from that experienced by men. In particular, research on precarious workers has highlighted the difficulty of combining unpredictable working hours with caring responsibilities. ${ }^{32}$ This is especially acute for those workers with no guaranteed working hours, often summarised in the label 'zero-hours contract'. In the UK, 54\% of these workers are women and their typical weekly working hours are less than those of male zero-hours contract workers; $37.4 \%$ of women worked less than 15 hours per week compared to $29.4 \%$ of men. ${ }^{33}$

\section{a. Gender Equality after the Part-Time Work Directive}

By the time of the adoption of the Part-Time Work Directive in 1997, there had already been a significant body of case-law from the CJEU recognising that less favourable treatment of part-time workers could constitute indirect sex discrimination, where women were over-represented amongst those working part-time. ${ }^{34}$ This caselaw often related to threshold requirements in terms of weekly working hours, below which the worker was excluded from benefits such as sick pay, ${ }^{35}$ bonuses, ${ }^{36}$ or severance payments. ${ }^{37}$ The Framework Agreement on Part-Time Work prohibited less

\footnotetext{
${ }^{27}$ European Foundation (n16) 10.

28 ibid 19.

${ }^{29}$ European Commission (n18) 216.

${ }^{30}$ Some forms of self-employment share features of precariousness, in particular those characterised by strong economic dependence on a single provider of work and/or where self-employment is a mechanism to circumvent employment law and social security protections: Rodgers (n5) 5 .

${ }^{31}$ European Commission (n18) 216.

${ }^{32}$ Marlea Clarke, Wayne Lewchuk, Alice de Wolff, and Andy King, “"This just isn't sustainable”: Precarious Employment, Stress and Workers' Health' (2007) 30 International Journal of Law and Psychiatry 311, 322.

${ }_{33}$ TUC, 'The Decent Jobs Deficit' (TUC 2014) 29-30.

${ }^{34}$ For an overview, see Deirdre McCann, Regulating Flexible Work (OUP 2008) 61; Evelyn Ellis and Philippa Watson, EU Anti-Discrimination Law (2nd edn, OUP 2012) 148.

${ }^{35}$ Case 171/88 Rinner-Kuhn v FWW Spezial-Gebaudereinigung GmbH \& Co KG [1989] ECR 2743.

${ }^{36}$ Case C-281/97 Krüger v Kreiskrankenhaus Ebersberg [1999] ECR I-5127.

${ }^{37}$ Case C-33/89 Kowalska v Freie und Hansestadt Hamburg [1990] ECR I-2591.
} 
favourable treatment in employment conditions of part-time workers compared to full-time workers, subject to the possibility of objective justification. ${ }^{38}$ Having created a specialised legal remedy for part-time workers, the question arose as to its relationship with the pre-existing route of indirect sex discrimination.

The initial response from the CJEU appeared to indicate a preference for regulation via gender equality legislation. In Steinicke, ${ }^{39}$ a part-time worker challenged a national rule that limited access to a special scheme of pre-retirement part-time work to those who had worked full-time for three out of the previous five years. While the referring court queried the compatibility of this requirement with both the Framework Agreement on Part-Time Work and gender equality legislation, the Court tersely determined that, as the facts fell within the scope of the Equal Treatment Directive, there was no need to consider the applicability of the Framework Agreement. ${ }^{40}$ Subsequent case-law has, though, recognised the possibility of combining both instruments within a single case and Advocates-General have taken the view that there is no particular hierarchy between them. ${ }^{41}$ With this in mind, female litigants would appear best advised to invoke both if possible. ${ }^{42}$ The shortcomings of relying only on the Framework Agreement were exposed in Mascellani. ${ }^{43}$ This concerned an Italian court official who had been working part-time (three days per week) since 2000. She used the remainder of her time to care for her family, including a 90 year old parent who lived with her, as well as pursuing a university degree. ${ }^{44}$ In 2011, she was unilaterally informed that she would have to work full-time over six days per week. The CJEU held that the Framework Agreement on Part-Time Work did not preclude an employer requiring a part-time worker to change to full-time work, even without the worker's consent. ${ }^{45}$ It rejected the idea that this constituted less favourable treatment on the basis that no comparable situation for a full-time worker could be identified. ${ }^{46}$

\footnotetext{
${ }^{38}$ Clause 4(1).

${ }^{39}$ Case C-77/02 Steinicke v Bundesanstalt für Arbeit [2003] ECR I-9027.

40 ibid para. 52.

${ }^{41}$ para. 67, Opinion of AG Kokott, Case C-313/02 Wippel v Peek \& Cloppenburg GmbH \& Co KG [2004] ECR I-9483; para. 28, Opinion of AG Ruiz-Jarabo Colomer, Cases C-55/07 and C-56/07 Michaeler, Subito GmbH, and Volgger v Amt für sozialen Arbeitsschutz, Autonome Provinz Bozen [2008] ECR I-3135.

${ }^{42}$ A male part-time worker could, of course, raise the indirect sex discrimination argument, but this would require evidence that men were over-represented amongst the part-time workers affected by the treatment in question.

${ }^{43}$ Case C-221/13 Mascellani v Ministero della Giustizia, EU:C:2014:2286.

44 para. 18, Opinion of AG Wahl, Case C-221/13 Mascellani v Ministero della Giustizia, EU:C:2014:479.

45 para. 24 , CJEU.

${ }^{46}$ para. 27 , CJEU.
} 
The reasoning in Mascellani placed considerable emphasis on the role played by part-time work in furthering labour market flexibility. ${ }^{47}$ In 1996, Italian law had granted a right to public sector employees to change from full-time to part-time employment, but in 2008 this was qualified by the addition of a requirement that such a change would not prejudice the good functioning of the organisation. ${ }^{48} \mathrm{~A}$ further reform in 2010 provided the state with a 180 day period to review the working time of those granted part-time work under the 1996 law, such as Ms. Mascellani. ${ }^{49}$ These legislative reforms were linked by the state to the sustainability of public finances, ${ }^{50}$ and Advocate-General Wahl accepted the premise that the Framework Agreement on Part-Time Work permits Member States to 'reduce the level of protection afforded under their rules on part-time work in times of turmoil'. ${ }^{51}$ The effects on the individual part-time worker appear to be a lower priority: 'a worker is always at liberty to end the employment relationship if he or she does not wish to work fulltime'. ${ }^{52}$ This is a remarkably thin concept of liberty, which pays little regard to the reality of choice for those with caring responsibilities. Frequently, it is the lack of accessible or affordable care services that compel the worker to work part-time. ${ }^{53}$ Mascellani exposes one dimension to the precariousness of part-time work; if the employer retains the unilateral prerogative of revoking part-time working, even after a period of over ten years in this case, the worker is left with considerable insecurity. It is, therefore, worth reflecting on whether gender equality legislation could have provided a different outcome.

Article 2(1)(b) of the Gender Equality (Recast) Directive provides the following definition of indirect discrimination:

Where an apparently neutral provision, criterion or practice would put persons of one sex at a particular disadvantage compared with persons of the other sex, unless that provision, criterion or practice is objectively justified by a legitimate aim, and the means of achieving that aim are appropriate and necessary. ${ }^{54}$

Given the over-representation of women in part-time work, the situation where an employer requires part-time workers to change their hours to full-time work will

\footnotetext{
47 ibid para. 25 .

${ }^{48}$ para. 3.1, Sentenza n.224/2013, Corte Costituzionale.

49 ibid.

50 ibid para. 2.3.2.

${ }^{51}$ para. 54, Opinion of AG Wahl.

52 ibid para. 53.

${ }^{53}$ European Commission, 'Report on Equality between Women and Men - 2010' (Luxembourg:

Publications Office of the European Union 2010) 40.

${ }^{54}$ European Parliament and Council Directive 2006/54 (EC) on the Implementation of the Principle of Equal Opportunities and Equal Treatment of Men and Women in Matters of Employment and Occupation (Recast) [2006] OJ L204/23.
} 
frequently place women at a particular disadvantage compared to men. While being offered longer working hours might be viewed as a benefit by some workers (most obviously those who are under-employed and seeking additional work), the data cited earlier indicated that in most Member States this was a minority of those in part-time work. More specifically, the sub-group of those working part-time and combining this with caring responsibilities will be disadvantaged by a unilateral change in their working hours given the potential disruption to their ability to combine work and family life; women are commonly over-represented in this sub-group. Mascellani exposed the shortcomings of the comparator test within the Framework Agreement on Part-Time Work; this requires a comparable full-time worker and the CJEU denied that any existed for the situation of a part-time worker required to become a full-time worker. Proceeding via the indirect sex discrimination route should shift the focus of the inquiry away from a strict comparator test and onto the potential justification for the employer's practice. ${ }^{55}$ This would demand a more searching and rigorous analysis than the loose references to labour market flexibility in Mascellani. It was unclear from the proceedings why compelling some workers to increase their working time would make a significant contribution to improving public finances. It must also be borne in mind that the CJEU has held that 'budgetary considerations cannot justify discrimination against one of the sexes. ${ }^{, 56}$ At a minimum, invoking gender equality legislation would have ensured a more balanced weighing of the interests of the employer and the worker, as well as rendering visible the gendered consequences of prioritising labour market flexibility in this fashion.

\section{b. Gender Equality and Other Forms of Precarious Work}

While part-time work provides the most frequent examples of gender equality law interacting with precarious work, there are other instances of intersection. Notably, legislation and case-law aim to secure rights relating to pregnancy, maternity and parental leave for non-standard workers. With regard to the protection of pregnant workers, the CJEU has held that it is unlawful to dismiss a fixed-term worker who cannot complete the full duration of the contract due to pregnancy. ${ }^{57} \mathrm{In}$ addition, it constitutes unlawful sex discrimination if an employer's reason for failing to renew a

\footnotetext{
${ }^{55}$ Although the CJEU has, at times, also imposed a comparator test within indirect sex discrimination, as discussed in the next section of this paper. ${ }_{56}$ para. 85, Cases C-4/02 and C-5/02 Schönheit v Stadt Frankfurt a.M., Becker v Land Hessen [2003] ECR I-12575.

${ }^{57}$ para. 31, Case C-109/00 Tele Danmark A/S v Handels- og Kontorfunktioncerernes Forbund I Danmark (HK) [2001] ECR I-6993.
} 
fixed-term contract is the worker's pregnancy. ${ }^{58}$ The Court has also sought to ensure that those persons whose working arrangements lie on the boundary between employment and self-employment are not deprived of protection. In Danosa, ${ }^{59}$ the complainant was appointed to be the sole member of a Board of Directors for a limited liability company. Seven months later, the general meeting of the shareholders of the company decided to remove her from this position. At the time, she was 11 weeks pregnant and she brought a case challenging her dismissal. The company argued that this was a commercial contract rather than one of employment. In contrast, the CJEU felt that the core elements of its concept of 'worker' were present: remuneration was provided for services performed and she was carrying out services under direction or control, even if the latter was quite limited. ${ }^{60}$ Accordingly, she enjoyed protection from dismissal due to pregnancy. ${ }^{61}$ As mentioned earlier, not all forms of self-employment have characteristics of precariousness. Danosa provides an illustration of circumstances where the relationship may be treated by national law as self-employment, yet the individual appears to be dependent upon a sole organisation for her principal source of income. Depriving such individuals of the benefit of employment protection legislation heightens their precariousness, so the wide reading of 'worker' adopted by the CJEU in this case helps to guarantee a floor of protection. Recent legislation strikes a similar chord. The Revised Parental Leave Directive expressly applies to part-time, fixed-term and agency workers, ${ }^{62}$ while Directive $2010 / 41^{63}$ applies the principle of equal treatment between women and men to those pursuing 'an activity in a self-employed capacity'. ${ }^{64}$

These examples of gender equality law and instruments on the reconciliation of work and family life being applied to non-standard work must, however, be balanced by instances that expose shortcomings in the response to precariousness. Specifically, the comparator test applied by the Court when identifying the possibility of sex discrimination can rebound upon the complainant where, due to precariousness,

\footnotetext{
58 para. 46, Case C-438/99 Jiménez Melgar v Ayuntamiento de Los Barrios [2001] ECR I-6915.

${ }^{59}$ Case C-232/09 Danosa v LKB Lìzings SIA [2010] ECR I-11405.

60 ibid para. 51.

61 ibid para. 74.

${ }^{62}$ Clause I(3), Council Directive (EU) 2010/18 implementing the Revised Framework Agreement on Parental Leave Concluded by BUSINESSEUROPE, UEAPME, CEEP and ETUC and Repealing Directive 96/34/EC [2010] OJ L68/13.

${ }^{63}$ European Parliament and Council Directive (EU) 2010/41 on the Application of the Principle of Equal Treatment between Men and Women Engaged in an Activity in a Self-Employed Capacity and Repealing Council Directive 86/613/EEC [2010] OJ L180/1.

64 ibid Art 1(1). The Court has also held that men should not be deprived of parental leave rights by virtue of their female partner being self-employed rather than employed: Case C-104/09 Roca Alvarez v Sesa Start España ETT SA [2010] ECR I-8661; Case C-5/12 Betriu Montull v INSS, EU:C:2013:571.
} 
her circumstances are deemed to be incomparable to those in a standard employment relationship. This can be witnessed in two examples.

The case of Allonby ${ }^{65}$ concerned a part-time lecturer who had been working for six years on a succession of one-year contracts and who was paid on an hourly basis. For financial reasons, her College decided to cease direct employment of parttime lecturers and instead to recruit them via a temporary employment agency, where they were treated as self-employed. Ms. Allonby was dismissed, but then continued to work for the College via the agency. This had the effect, however, of reducing her salary and depriving her of certain employment benefits, such as exclusion from the occupational pension scheme for teachers. The issue of sex discrimination arose as a significantly higher number of female teachers were affected by this reorganisation. ${ }^{66}$ While the CJEU held that she was a worker for the purposes of EU gender equality law, it rejected the possibility for her to compare her salary with that of the teachers who remained directly employed by the College. ${ }^{67}$ The Court took the view that comparators, for the purposes of equal pay law, had to have a single source of income. As she was paid by the agency, she could not compare herself to those paid directly by the College. From any standpoint, Ms. Allonby's situation as a part-time, temporary worker has the hallmarks of precariousness. Yet the employer succeeded in evading the application of equal pay law through its efforts to accentuate her precariousness by inserting an employment agency into their pre-existing relationship.

Another example of the significance of how the comparator test is deployed can be found in Wippel. $^{68}$ This case involved a retail worker who was hired on a 'work on demand' contract. She had no guaranteed hours and these were determined on a case-by-case basis, with the possibility for her to decline hours that the company offered to her. She argued that this was both less favourable treatment of part-time workers and indirect sex discrimination on the basis that, unlike other full-time and part-time workers, she had no pre-determined salary based on a guaranteed level of weekly hours. ${ }^{69}$ The Court rejected her actions under both the Framework Agreement on Part-Time Work and the Equal Treatment Directive. It held that she was not in a comparable situation to other workers whose contracts provided for fixed working

\footnotetext{
${ }^{65}$ Case C-256/01 Allonby v Accrington \& Rossendale College [2004] ECR I-873.

${ }^{66}$ Of those made redundant and then re-employed via the agency, 231 were women and 110 were men. Of those retained as directly employed lecturers by the College, the majority were men (para. 11, Opinion of AG Geelhoed, 2 April 2003).

${ }^{67}$ para. 50, CJEU.

${ }^{68}$ Case C-313/02 Wippel v Peek \& Cloppenburg GmbH \& Co. KG [2004] ECR I-9483.

69 ibid para. 52.
} 
hours because workers in her situation had the choice of accepting or refusing the hours offered. ${ }^{70}$ The significance of this case has, if anything, grown over time. In some Member States, the economic crisis has witnessed a growth in casual work. In the UK, for example, there has been an increase in agency work, casual work and zero-hours contracts since $2008 .{ }^{71}$ In $2004,4 \%$ of workplaces had some employees on zero-hours contracts ${ }^{72}$ (which are akin to the contractual arrangements found in Wippel), but this had risen to $10 \%$ in $2015 .{ }^{73}$ Casual work is a species of part-time work, yet its flexibility means that average weekly working hours can vary greatly; in some cases, the volume of work performed is more similar to full-time work. Moreover, the duration of some casual relationships can become extended; even Ms. Wippel had been employed for 21 months by the time she started legal proceedings. The decision in Wippel is problematic, because it implies that differences in contractual terms can render a particular group of workers incomparable to all others, thereby excluding any recourse to the protections available under either the Directives on atypical work or those on equality. Arguably, this needs to be reconsidered.

In Wippel, the claim was one of indirect sex discrimination. While the legislative definition of direct discrimination refers to the identification of another person 'in a comparable situation', ${ }^{74}$ this is absent from the definition of indirect discrimination. ${ }^{75}$ It is, therefore, a conflation of the two concepts for the Court to preclude an analysis of possible indirect discrimination on the basis that the two groups of workers being compared are dissimilar. If, in a given workplace, those working under zero-hours contracts are disproportionately women, ${ }^{76}$ then practices that treat such workers less favourably place women at a particular disadvantage in comparison to men. Indirect discrimination is, of course, balanced by the possibility for objective justification of the practice in question. This provides the juncture at which the employer may be able to bring forward sufficient reasons for why zero-

\footnotetext{
70 ibid para. 59-64.

${ }^{71}$ Ian Brinkley, 'Flexibility or Insecurity? Exploring the Rise in Zero Hours Contracts' (Lancaster: The Work Foundation 2013) 24.

72 Doug Pyper and Feargal McGuinness, 'Zero-Hours Contracts' SN/BT/6553 (House of Commons Library 2014) 4.

${ }^{73}$ Doug Pyper and Jeanne Delebarre, 'Zero-Hours Contracts' Briefing Paper No. 6553 (House of Commons Library 2016) 6. It was estimated that 903,000 people in the UK were working under zerohours contracts in 2016.

${ }^{74}$ Art 2(1)(a), Directive 2006/54.

${ }^{75}$ Art 2(1)(b), ibid.

${ }^{76}$ Notably, AG Kokott did not approach the question of indirect sex discrimination in the same manner as that of the Court. She focused on the relative proportions of women and men employed via on demand contracts (84.84\% women) and those employed on fixed-hours contracts (75.82\% women). She felt that the difference in the proportion of women working on demand or with fixed-hours was not sufficient to establish indirect discrimination (para. 121 (n41)).
} 
hours contract workers are treated differently to their fixed-hours counterparts. For example, in Wippel, Advocate-General Kokott expressed the view that work on demand contracts were not inherently disadvantageous to workers, but if the manner in which they were used gave rise to abuse, then a finding of indirect sex discrimination could occur. ${ }^{77}$ This approach might not have resulted in a positive outcome for Ms. Wippel, but it would be a better foundation for analysing future indirect discrimination claims from those engaged in types of casual work.

\section{Age Equality and Precarious Work}

The previous section considered how gender equality legislation has been used in relation to precarious work. Given the link between part-time work and female employment in many EU states, there is a well-established body of case-law exploring these issues, which has revealed some of the opportunities, and constraints, within the approach of the CJEU. The second part of this paper turns to consider issues of age and precarious work. This is a more recent evolution as the prohibition on age discrimination in the Employment Equality Directive dates from 2000 and some Member States availed of the extended implementation period that ran until 2006. ${ }^{78}$ While the volume of case-law tackling these issues is more limited, there are early signs of how age and precarious work intersect.

\section{a. Age, Precarity and the Labour Market}

While precarious work can affect persons of all ages, there is some evidence that it impacts particularly heavily on both younger and older workers. Certainly, these groups are over-represented in non-standard forms of employment. As mentioned earlier, $19.6 \%$ of employment in the EU is part-time, ${ }^{79}$ but this figure rises to $32 \%$ for $15-24$ year olds ${ }^{80}$ and $38 \%$ for those over $65 .{ }^{81}$ Younger people often engage in parttime working in conjunction with studying, while older people may have recourse to part-time working as a type of partial retirement. Insofar as these forms of work are freely chosen, this may be beneficial for all parties. Yet young people, in particular,

\footnotetext{
77 ibid para. 125 .

${ }^{78}$ Council Directive 2000/78 (EC) Establishing a General Framework for Equal Treatment in Employment and Occupation [2000] OJ L303/16.

${ }^{79}$ European Commission (n18) 215.

${ }^{80}$ Eurostat Statistical Books, 'Being Young in Europe Today' (Publications Office of the EU 2015) 154.

${ }^{81}$ European Foundation for the Improvement of Living and Working Conditions, 'Work Preferences After 50' (European Foundation 2014) 9.
} 
frequently encounter involuntary part-time work. This phenomenon has grown during the economic crisis with $30 \%$ of $15-24$ year olds in the EU citing the impossibility of finding a full-time job as the reason why they were working part-time. ${ }^{82}$ In some states, involuntary part-time work amongst young people is strikingly high; it constitutes more than two-thirds of young people working part-time in Italy, Romania, Greece and Spain. ${ }^{83}$

Young people are also over-represented amongst those in temporary employment. While $13.8 \%$ of employees in the EU have fixed-term contracts, ${ }^{84}$ this figure rises to $22 \%$ of those aged $25-29$, and $43 \%$ of $15-24$ year olds ${ }^{85}$ Research by the European Foundation found evidence that one in five workers aged 15-29 were engaged in 'very atypical' forms of work, such as having no employment contract, working less than 10 hours per week or having a temporary contract with a duration of less than six months. ${ }^{86}$ This data preceded the economic crisis and, in some states, this has resulted in a growth in precarious working by young people. In the UK, for example, $39.6 \%$ of those employed under zero-hours contracts are aged 16-24, while the same age cohort represents $23.4 \%$ of agency workers. ${ }^{87}$ While there is strong evidence of precarious forms of working affecting young people, data also indicates that 'very atypical' work increases amongst those over $50 .{ }^{88}$ There is also evidence that people aged over 55 are strongly over-represented amongst those in selfemployment. ${ }^{89}$ More generally, older workers are affected by insecurity of employment. This is particularly true where national law permits mandatory retirement, which places workers on any type of contract at risk of dismissal once they have exceeded the age threshold. ${ }^{90}$

\section{b. Older Workers and Recourse to Fixed-Term Contracts}

Several cases have shone a light on practices that expose older workers to an elevated risk of being employed via a fixed-term contract. This lay at the heart of the Court's first engagement with age discrimination in Mangold $v$ Helm. ${ }^{91}$ In this famous

\footnotetext{
${ }^{82}$ Eurostat Statistical Books (n80) 157.

83 ibid 156.

${ }^{84}$ European Commission (n18) 257.

${ }^{85}$ Eurostat Statistical Books (n80) 153.

${ }^{86}$ European Foundation (n16) 14.

${ }^{87} 16-24$ year olds form $13 \%$ of the working age population: TUC (n33) 20.

${ }^{88}$ European Foundation (n16) 14.

${ }^{89}$ Susan Bisom-Rapp, Andrew Frazer and Malcolm Sargeant, 'Decent Work, Older Workers and Vulnerability in the Economic Recession: a Comparative Study of Australia, the United Kingdom and the United States' (2011) 15 Employee Rights and Employment Policy Journal 43, 85.

90 ibid 81.

${ }^{91}$ Case C-144/04 Mangold v Helm [2005] ECR I-9981.
} 
decision, the Court held that a provision of German law that permitted recourse to fixed-term contracts without the need for objective justification for those over the age of 52 constituted direct age discrimination that lacked sufficient justification. ${ }^{92}$ This signalled the potential for the Employment Equality Directive to fill some of the gaps in protection found in the Framework Agreement on Fixed-Term Work. Mangold concerned the conditions under which an employee could be initially hired under a fixed-term contract. While the Framework Agreement regulates the successive use and renewal of such contracts, it does not, according to the CJEU, impose restrictions on the first occasion when a fixed-term contract is issued to a worker. ${ }^{93}$

Mangold indicated the potential of the Employment Equality Directive to challenge the idea that retaining older workers in the labour market provides a blanket justification for any form of reduction in employment protection standards.

Subsequent cases have, though, demonstrated more caution on the part of the Court. In Georgiev, ${ }^{94}$ Bulgarian law required professors to retire at 65 , but permitted the extension of their employment through recourse to fixed-term contracts valid for 12 months, with a ceiling of three additional years of employment. The CJEU accepted that this was a difference of treatment based on age because the employment conditions of such professors became 'more precarious' than those under 65 employed on contracts of indefinite duration. ${ }^{95}$ It concluded, however, that using fixed-term contracts in this manner was capable of justification. To this end, it argued:

1. this reflected 'an employment policy which seeks inter alia to encourage the promotion of younger teaching staff to posts as university professors'; ${ }^{96}$

2. the professors would be entitled to a retirement pension by this age;

3. the maximum number and duration of fixed-term contracts were compatible with the requirements on preventing abuse within the Framework Agreement on Fixed-Term Work.

Focusing on the question of precarious work, it is important to disentangle the general justifications for mandatory retirement and the specific justifications for the recourse to fixed-term contracts witnessed in this case. The Court cited the need to encourage the recruitment of younger teaching staff. Setting to one side the doubts over whether

\footnotetext{
92 ibid para. 65 .

93 ibid paras 40-43.

${ }^{94}$ Joined Cases C-250/09 and C-268/09 Georgiev v Tehnicheski universitet - Sofia, filial Plovdiv

[2010] ECR I-11883.

95 ibid para. 34.

96 ibid para. 61.
} 
mandatory retirement necessarily leads to more posts for younger staff, ${ }^{97}$ it is difficult to identify how the policy of permitting extension via fixed-term contracts pursues that aim. Indeed, it could be argued that this runs counter to the stated aim insofar as it might lead to a delay in the appointment of a younger replacement. It is also difficult to see how the fact that the professor was entitled to a pension provides a justification for the use of a fixed-term contract. Again, this seems to be a justification for mandatory retirement rather than extended working under temporary contracts. Finally, while the Court is correct that limiting the use of fixed-term contracts to a maximum period of three years, including two renewals, is not, on the face of it, contrary to the Framework Agreement, this misses the context to the employment relationship. This was not the first hiring of a worker, but rather the continuation of a prior contract of indefinite duration. Arguably, the Framework Agreement is premised on a transition towards a contract of indefinite duration, rather than contractual changes in the opposite direction. Overall, the justifications advanced by the Court do not seem tailored to the specific practice of extending employment via fixed-term contracts, rather than permitting the worker to retain their pre-existing contractual terms. In truth, the underlying justification appears to be a broader sense of flexibility for the employer as placing these professors on fixed-term contracts 'makes it possible to secure their departure after a relatively brief period and thus to appoint younger professors in their stead' ${ }^{98}$

The case of Kumpan $^{99}$ also concerned the use of fixed-term contracts following mandatory retirement. Ms. Kumpan was a flight attendant for Lufthansa and, in accordance with the applicable collective agreement, her indefinite contract of employment ended when she turned 55. There was, however, a provision for multiple 12 month renewals of the employment contract, which could continue until the age of 60 . As she was approaching the age of 60 , she challenged the limitation on her fixedterm contract. Her situation was compounded by a provision of German law providing that objective justification for the conclusion of a fixed-term employment contract was not required for those over the age of $58 .{ }^{100}$ Although the referring court queried the compatibility of this practice with both the Employment Equality Directive and the Framework Agreement on Fixed-Term Work, the Court chose to focus on the

\footnotetext{
${ }^{97}$ eg the posts might not be replaced if there is a need for financial savings, or they might be replaced at a lower grade.

${ }_{98}$ ibid para. 61. See also, Opinion of AG Bot, para. 40.

${ }^{99}$ Case C-109/09 Deutsche Lufthansa AG v Kumpan, EU:C:2011:129.

100 ibid para. 10.
} 
latter. Clause 5(1) requires Member States to make a choice concerning the measures to be put in place to prevent the abusive recourse by employers to successive fixedterm contracts. In this case, national law did not apply any conditions relating to the successive use of fixed-term contracts for workers who exceeded the age of 58 . The CJEU held that this failed to comply with the obligations arising in the Framework Agreement. ${ }^{101}$ In the light of this conclusion, the Court held, without elaboration, that it was unnecessary to address the potential conflict with the Employment Equality Directive. ${ }^{102}$

The decisions in Mangold, Georgiev and Kumpan indicate that the Court will apply a strict level of scrutiny to legislative measures that exclude older workers from laws regulating fixed-term work, especially if these apply in an abstract fashion to all workers over a given age. It may also be an influential factor that Mangold and Kumpan concerned workers aged in their fifties when eligibility for a pension may be limited. In contrast, the Court seems more disposed to permit departures from the normal standards on fixed-term work in respect of workers who are already entitled to a pension and where the use of such contracts is for a limited period. Yet pension entitlement is a problematic criterion because mere qualification for a pension does not determine the level of that pension. Some workers wish to continue working to enhance the level of their pension; given that women more frequently interrupt their careers for caring responsibilities, combined with periods of part-time work, they may have a particular motivation for continuing to work irrespective of pension eligibility. ${ }^{103}$ Moreover, Clause 5(1) of the Framework Agreement does not specify any upper threshold on the number of renewals of fixed-term contracts to be permitted, nor their maximum duration. While the Court viewed the Bulgarian practice in Georgiev of two renewals within three years as complying with Clause 5(1), it remains unclear whether Lufthansa's practice of four renewals within five years was also acceptable. In Kumpan, the Court focused on the age limit in the national legislation on fixed-term work, rather than the approach taken in the collective agreement.

\section{c. Precarity and Younger Workers}

There is a smaller volume of case-law dealing with age discrimination in relation to younger workers, but a number of examples illustrate how age thresholds can expose

\footnotetext{
101 ibid para. 43.

102 ibid para. 58.

${ }^{103}$ Dagmar Schiek, 'Age Discrimination Before the ECJ - Conceptual and Theoretical Issues' (2011)

48 Common Market Law Review 777, 795.
} 
younger workers to reduced employment protection. The case of Hütter ${ }^{104}$ related to an Austrian provision excluding periods of employment under the age of 18 from counting towards length of service entitlements. This delayed progress through salary scales, with effects on pay that would endure over time. The Court found the justifications advanced for this provision to be contradictory and not appropriate to the objective of promoting young people's access to the labour market. ${ }^{105}$ Notably, the Danish government had argued that lower rates of pay for younger workers could be justified as a measure to promote their integration into the labour market. ${ }^{106}$ It invoked the justification for differences of treatment based on age found in Article 6(1)(a) of the Employment Equality Directive:

the setting of special conditions on access to employment and vocational training, employment and occupation, including dismissal and remuneration conditions, for young people, older workers and persons with caring responsibilities in order to promote their vocational integration or ensure their protection.

The CJEU distinguished lower rates of pay based on age from the facts arising in Hütter ${ }^{107}$ thereby leaving open the possibility that such measures might be justifiable in other circumstances.

In Kücükdeveci, ${ }^{108}$ the notice to which an employee was entitled prior to dismissal accrued with length of service, but to the exclusion of periods of service under the age of 26 . The complainant received one month's notice, whereas she would have been entitled to four months if her service when she was younger than 26 had been taken into account. The referring court stated that this measure aimed 'to afford employers greater flexibility in personnel management by alleviating the burden on them in respect of the dismissal of young workers, from whom it is reasonable to expect a greater degree of personal or occupational mobility'. ${ }^{109}$ As in Hütter, the CJEU was not persuaded by this reasoning, especially given that the effects of discounting service before 26 applied irrespective of the employee's actual age at the time of dismissal. ${ }^{110}$

Given the very high levels of youth unemployment in some Member States, there is a difficult balance to be struck between incentivising employers to recruit young people and avoiding measures that exacerbate the precarious position of young

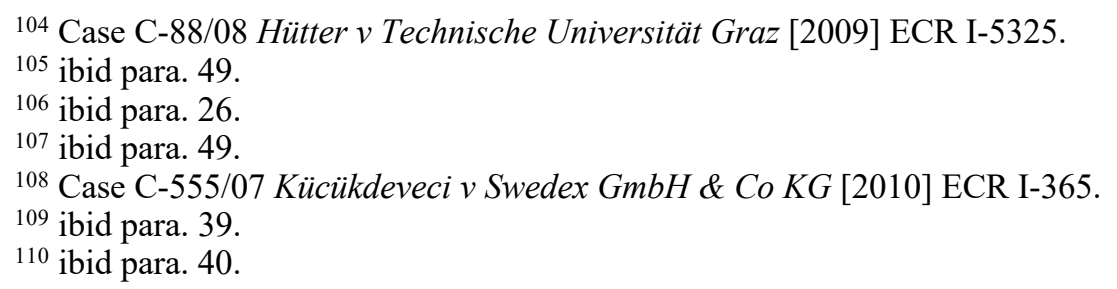


workers. Kountouris draws attention to the role that legislation can play in creating precariousness in the labour market; ${ }^{111}$ this can be the case where law reduces the normal level of employment protection based on age, such as lower minimum wage entitlements. While young people are evidently over-represented amongst those affected by precariousness, it is notable that relatively few cases have reached that CJEU that deal with their working conditions. This may reflect the inherent obstacles to litigation that those in the most precarious jobs encounter, such as the financial costs entailed and the difficulty of trade union organisation within casualised work. In contrast, it is notable that the litigants in Georgiev and Kumpan were experiencing precariousness after lengthy periods of permanent employment, so may have been better equipped to pursue a legal challenge. While the flexibility provided by Article 6 of the Employment Equality Directive indicates that some age-based deviations from the standard levels of employment protection can be sustained, the merits of the justification test is that it exposes these to scrutiny with regard to their appropriateness and proportionality. The cases considered in this section indicate the potential for the Directive to play a part in querying whether measures that exacerbate precariousness necessarily contribute to the labour market integration of younger or older people. The Court will have a further opportunity to consider these issues in the pending case of Abercrombie \& Fitch Italia Srl v Bordonaro, ${ }^{112}$ which concerns a provision of national law permitting the use of on-call contracts of employment for those under the age of 25 .

\section{Conclusions}

Although the late 1990s witnessed both the adoption of the Atypical Work Directives and the expansion of EU equality legislation, there was relatively little crossfertilisation between these instruments at their inception, with the notable exception of part-time work and gender equality. Changes in the labour market since then, and especially during the economic crisis, have seen an expansion in non-standard forms of employment. The empirical data discussed in this paper indicate that some groups are more affected by labour market precarity than others. It is, therefore, relevant to consider the role that EU equality law can play in combating precariousness.

The examples considered in this paper show that there is often an intersection in the application of the Atypical Work Directives and the Equality Directives. At

\footnotetext{
111 Kountouris (n7).

112 Case C-143/16. See further: <http://eulawradar.com/case-c-14316-abercrombie-and-fitch-italyslabour-law-for-the-under-25s/> accessed 21 February 2017.
} 
times, the issue is framed by courts (and presumably also by litigators) as one or the other; for example, in Mascellani, the referring court did not raise the possibility of indirect sex discrimination, while in Kumpan, the CJEU decided that it did not need to address separately the question of age discrimination. This is unhelpful, because it overlooks the substantive differences between the Directives; arguably, the equality directives impose a more rigorous standard of protection than that found in the legislation on atypical work. Moreover, sidelining the equality dimension to such cases obscures the disparate impact of precariousness on certain groups in the labour market, such as women and younger or older workers. To be clear, this chapter is not arguing that the Equality Directives should displace the role of the Atypical Work Directives; instead, there is a need to ensure that the potential application of both sources of law are considered in litigation.

The experience of gender equality legislation provides the clearest evidence of how equality law can assist in tackling precarious working conditions. The CJEU case-law has undoubtedly made a contribution to ensuring that part-time workers have access to the same range of benefits and protections as full-time workers. Such litigation has been aided by the accumulation of data that frequently establishes a strong over-representation of women amongst part-time workers. Data is often less available in relation to other protected characteristics and other forms of non-standard work. For example, there seems to be less data on the experience of disabled workers in terms of their types of employment relationship, and data on casual employment relationships is more sparse. These gaps in information may hinder efforts to identify patterns of indirect discrimination.

The case-law considered here demonstrated that litigants in the most precarious forms of employment may encounter greater obstacles to relying on equality law. In particular, rigid applications of the comparator test, such as those seen in Allonby or Wippel, threaten to compound precariousness by rendering it very difficult for some workers to invoke equality law protections. ${ }^{113}$ Their cases stumble at the initial hurdle of comparability, thereby preventing any analysis of the justification for the difference in their treatment. Given the growth in non-standard forms of work, combined with evidence that this affects some groups more than others, the effectiveness of equality law will depend on the Court being willing to

\footnotetext{
${ }^{113}$ Leah Vosko, Managing the Margins - Gender, Citizenship and the International Regulation of Precarious Employment (OUP 2010) 101.
} 
move away from a narrow approach that uses the comparator test to filter out claims from non-standard workers.

Overcoming the comparator test does not imply that equality law will offer a panacea for all the problems experienced by those in precarious work. The case-law on age discrimination drew out the balancing act between the claimed pursuit of labour market flexibility on the one hand, and the principle of equal treatment on the other. In some cases, such as Mangold, Hütter and Kücükdeveci, the Court was searching in its review of flexibility-based justifications and it was willing to question the coherence of national labour market policy. Yet Georgiev indicates that sometimes the degree of scrutiny applied by the Court is lighter, which may reflect the wider margin of discretion that it has afforded Member States in relation to mandatory retirement. ${ }^{114}$ The regulation of precarious work is inevitably intertwined with debates on labour market flexibility, so it can be expected that attempts to use equality law to challenge precarity will present the Court with similar trade-offs. While the fundamental choices over the direction of labour market policy remain a matter for national and European governments, the objective justification test found within indirect discrimination can serve the purpose of exposing these choices to judicial scrutiny where they result in a disparate impact on women and minorities.

\footnotetext{
${ }^{114}$ Elaine Dewhurst, 'The Development of EU Case-Law on Age Discrimination in Employment: "Will You Still Need Me? Will You Still Feed Me? When I'm Sixty-Four?"' (2013) 19 European Law Journal 517, 534.
} 